\title{
Filling the Egyptian pollinator knowledge-gap: checklist of flower-visiting insects in South Sinai, with new records for Egypt
}

With 1 table

OLIVIA NORFOLK ${ }^{1}$ and HOLger H. DATHE ${ }^{2}$

${ }^{1}$ School of Life Sciences, Anglia Ruskin University, East Road, Cambridge, CB1 1PT, UK. - olivia_norfolk@hotmail.com
${ }^{2}$ Senckenberg Deutsches Entomologisches Institut, Eberswalder Straße 90, 15374 Müncheberg, Germany.
- Holger.Dathe@senckenberg.de
Published on 2019-06-24

DOI: 10.21248/contrib.entomol.69.1.175-184

\begin{abstract}
Flower visitor surveys were conducted across the St Katherine Protectorate of South Sinai, Egypt, between April-July 2012 and 2013. We present a checklist of 112 species of flower visitors belonging to the orders Coleoptera, Diptera, Hemiptera, Hymenoptera and Lepidoptera. The Hymenoptera were the most diverse group of flower visitors, consisting of 69 species from eight families: Apidae (14), Colletidae (8), Crabronidae (10), Halictidae (13), Megachilidae (19), Scoliidae (1), Sphecidae (2) and Vespidae (2). We recorded nine species that were endemic to the region and thirteen that were new to the Egyptian fauna, including one new to science, Hylaeus oliviae DATHE, 2015. The study provides a valuable initial checklist of pollinators within the St Katherine Protectorate, but the description of novel species and the high proportion of new records for Egypt suggest that species numbers are likely to be underestimated. We highlight the need for future research into Egyptian pollinator fauna, particularly within the St Katherine Protectorate where endemic bees are still being described.
\end{abstract}

\section{Key words}

Apidae, bee, butterfly, Colletidae, Crabronidae, Halictidae, hoverfly, Megachilidae, pollinator, Syrphidae, Tephritidae

\section{Zusammenfassung}

Jeweils von April bis Juli der Jahre 2012 und 2013 wurden im gesamten St. Katherine Protektorat Süd-Sinai (Ägypten) Blütenbesuche von Insekten registriert. Im Ergebnis entstand eine Checklist von 112 blütenbesuchenden Insektenarten aus den Ordnungen Coleoptera, Diptera, Hemiptera, Hymenoptera und Lepidoptera. Dabei waren die Hymenopteren mit 69 Arten aus acht Familien in der größten Vielfalt vertreten: Apidae (14 spp.), Colletidae (8), Crabronidae (10), Halictidae (13), Megachilidae (19), Scoliidae (1), Sphecidae (2) und Vespidae (2). Wir registrierten in der Region neun endemische Arten und 13 Arten als neu für die ägyptische Fauna, darunter eine für die Wissenschaft neue Spezies, Hylaeus oliviae DATHE, 2015. Die Studie liefert eine wertvolle erste Checklist von Bestäubern im St. Katherine Protektorat, wobei die Neubeschreibung und der hohe Anteil neuer Funde für Ägypten darauf hindeuten, dass die Artenzahlen wahrscheinlich noch unterschätzt werden. Wir betonen die Notwendigkeit weiterer Forschungen zur ägyptischen Bestäuberfauna, insbesondere im St. Katherine Protektorat, wo sicherlich noch weitere endemische Bienen zu finden sind. 


\section{Schlüsselwörter}

Apidae, Biene, Schmetterling, Colletidae, Crabronidae, Halictidae, Schwebfliege, Megachilidae, Bestäuber, Syrphidae, Tephritidae

\section{Introduction}

Flower-visiting insects provide valuable pollination services, helping to maintain yields of $75 \%$ of global crop species and an estimated $94 \%$ of wild flowering plants (KLEIN et al. 2007). Despite their high ecological and economic importance, current trends suggest that pollinators are experiencing widespread declines (Роттs et al. 2010). The strongest evidence for these declines comes from Europe and the USA, but there is a distinct lack of pollination research in arid regions such as Northern Africa and the Middle East (Ротts et al. 2010, MAYer et al. 2011, Archer et al. 2014). There is likely to be a variety of political and social barriers slowing pollinator research across the Middle East, but efforts to prioritise pollinator research will be essential if we hope to quantify and tackle on-going pollinator declines in the region.

Despite the disproportionate lack of pollination research in the region, Middle Eastern smallholder farms tend to be heavily reliant on the economic and nutritional returns associated with pollinator-dependent crops such as fruit and vegetables (Chaplin-Kramer et al. 2014, GAllai et al. 2009, STEWARD et al. 2014). This is particularly true in the mountains of South Sinai, Egypt, where the local Bedouin community are highly dependent on products grown within traditional orchards gardens. Wild pollinators have been shown to enhance the fruit set of the primary almond crop within the region (Norfolk et al. 2016) and many of the pollinator-dependent crops grown within the gardens are likely to experience similar yield benefits (GARIBALDI et al. 2013). An enhanced understanding of pollinator communities within such smallholder systems can help inform management practices that support pollination services and crop yields in the region.

The St Katherine Protectorate in South Sinai is rich in biodiversity and supports over half of Egypt's endemic flowering plants (AYYAD et al. 2000), many of which will also benefit from a diverse pollinator community. The region is known to support high butterfly diversity, with 40 of Egypt's 60 species present within the Protectorate (LARSEN 1990) and high levels of endemism have been reported within the Bombyliidae (EL-HAwAGRY \& GILBERT 2014). Other studies have assessed the diversity of beetles (SEMIDA et al. 2001), ground arthropods (Norfolk et al. 2012) and some flower visitors in the region (SEMIDA et al. 2001, ZALAT et al. 2001, ZALAT et al. 2009, Norfolk et al. 2012), but there have been few comprehensive surveys of the pollinator fauna within the Protectorate. Here, we provide a checklist of the flower visitor fauna from the St Katherine Protectorate during extensive surveys between April-July in 2012 and 2013.

\section{Methods}

We surveyed flower visitors in six localities within the St Katherine Protectorate between April-July in 2012 and 2013: Sheik Awad, St Katherine Town, Wadi Rahah, Wadi Itlah, Wadi Gebel and Wadi Tinya. Repeat monthly surveys were carried out in $500 \mathrm{~m}^{2}$ plots with all flowervisiting insects captured with a hand net (37 plots in 2012; 54 plots in 2013). Specimens were identified by C. O’Toole (Apidae), M. Kuhlmann and H. H. Dathe (Colletidae), A. Pauly (Halictidae), C. Praz and A. Müller (Megachillidae), C. Schmid-Egger (Sphecidae), A. Freidberg (Tephritidae) and O. Norfolk and F. Gilbert (Lepidoptera and Syrphidae). Reference specimens are stored in the personal collection of the first author and respective taxonomists (indicated by their initials). Distributions were determined according to Schuh et al. (2010), Kuhlman et al. (2014), Pauly (2011), Pauly (2016), Rasmont (2014), Kugler and Freidberg (1975), Peck (1988) and Schmid-Egger (2004).

\section{Results}

In total we recorded 112 species of flower visitors belonging to Coleoptera, Diptera, Hemiptera, Hymenoptera and Lepidoptera. The Hymenoptera were the most diverse group, consisting of 69 species from eight families: Apidae (14), Colletidae (8), Crabronidae (10), Halictidae (13), Megachilidae (19), Scoliidae (1), Sphecidae (2) and Vespidae (2). We recorded nine species endemic to the region and 13 that were new to the Egyptian fauna. We also present records for Hylaeus oliviae DATHE, 2015, which was described as new from specimens collected during this study, and for species Anthophora Sinai sp1 and Anthophora (Heliophila) Sinai sp1, which are probably new (official description pending access to reference collection). The list below provides details about species that are new to Egypt and/or have a restricted distribution. Table 1 is a full species list.

\section{APOIDEA}

Family: Apidae

\section{Anthophora pauperata WALKER, 1871}

Material: April 2012 - St Katherine town $28^{\circ} 33^{\prime} \mathrm{N}$, $33^{\circ} 56^{\prime} \mathrm{E}$ (3 우 우), Wadi Itlah $28^{\circ} 35^{\prime} \mathrm{N}, 33^{\circ} 55^{\prime} \mathrm{E}$ (1 우); April 2013 - St Katherine town $28^{\circ} 33^{\prime} \mathrm{N}, 33^{\circ} 56^{\prime} \mathrm{E}$ (2 우 우), Wadi Itlah $28^{\circ} 35^{\prime} \mathrm{N}, 33^{\circ} 55^{\prime} \mathrm{E}$ (1 우), Wadi Gebel $28^{\circ} 32^{\prime} \mathrm{N}, 33^{\circ} 55^{\prime} \mathrm{E}$ (1 + ). C.O’T. 
Details: Observed foraging on Alkanna orientalis (L.) Boiss, Zilla spinosa(L.) Prantl., Stachys aegyptiaca Pers. and Anchusa milleri SPRENG.

Distribution: Egypt and Saudi Arabia.

\section{Anthophora caelebs GRIBODo, 1924}

Material: April 2012- St Katherine town $28^{\circ} 33^{\prime} \mathrm{N}, 33^{\circ} 56^{\prime} \mathrm{E}$ (2 우 우), Wadi Gebel $28^{\circ} 32^{\prime} \mathrm{N}, 33^{\circ} 55^{\prime} \mathrm{E}$ (1 우). C.O’T.

Details: Observed foraging on A. orientalis and Z. spinosa.

Distribution: Libya, Egypt and Israel.

\section{Anthophora hermanni Schwarz \& GUSENLEITNER, 2003}

Material: April-May 2013- St Katherine town $28^{\circ} 33^{\prime} \mathrm{N}$, $33^{\circ} 56^{\prime} \mathrm{E}$ ( 1 우), Wadi Itlah $28^{\circ} 35^{\prime} \mathrm{N}, 33^{\circ} 55^{\prime} \mathrm{E}$ (1 우), Wadi Tinya, $28^{\circ} 34^{\prime} \mathrm{N}, 33^{\circ} 54^{\prime} \mathrm{E}$ (2 우 우).

Details: Observed foraging on A. orientalis. C.O’T.

Distribution: Egypt.

\section{Anthophora Sinai sp1}

Material: April-May 2013 - St Katherine town $28^{\circ} 33^{\prime} \mathrm{N}$, $33^{\circ} 56^{\prime} \mathrm{E}\left(21 \sigma^{\top} \sigma^{\top}\right)$, Wadi Itlah $28^{\circ} 35^{\prime} \mathrm{N}, 33^{\circ} 55^{\prime} \mathrm{E}$ (25 우 우), Wadi Gebel $28^{\circ} 32^{\prime} \mathrm{N}, 33^{\circ} 55^{\prime} \mathrm{E}$ (4웅), Wadi Tinya, $28^{\circ} 34^{\prime} \mathrm{N}, 33^{\circ} 54^{\prime} \mathrm{E}$ (1 우). C.O’T.

Details: Observed foraging on A. milleri, S. aegyptiaca and $Z$. spinosa. Pending access to type material of IranoTuranian species, this morphotype has been given a temporary designation and may be an undescribed species.

\section{Anthophora (Heliophila) Sinai sp1}

Material: May-June 2013 - Wadi Itlah $28^{\circ} 35^{\prime} \mathrm{N}, 33^{\circ} 55^{\prime} \mathrm{E}$ (2 ㅇ ๆ). C.O’T.

Details: Observed foraging on A. milleri and Tanacetum santolinoides Feinbrun \& Fertig. Pending access to type material of Irano-Turanian species, this morphotype has been given a temporary designation and may be an undescribed species.
Family: Colletidae

\section{Colletes tuberculatus Morawitz, 1894}

Material: June-July 2013 - Wadi Tinya, $28^{\circ} 34^{\prime} \mathrm{N}, 33^{\circ} 54^{\prime} \mathrm{E}$ (1 ㅇ) . M.K.

Details: Observed foraging on Achillea santolina L.

Distribution: Widespread across Eastern Palaearctic, including neighbouring Israel and Jordan. First record for Egypt.

\section{Hylaeus sinaiticus (AlFKEN, 1938)}

Material: May-June 2012 - St Katherine town $28^{\circ} 33^{\prime} \mathrm{N}$, $33^{\circ} 56^{\prime} \mathrm{E}\left(2 \sigma^{\top} 0^{\top}\right)$; April-July 2013 - St Katherine town $28^{\circ} 33^{\prime} \mathrm{N}, 33^{\circ} 56^{\prime} \mathrm{E}$ (2 우 우, $10^{\top}$ ), Wadi Rahah $28^{\circ} 34^{\prime} \mathrm{N}$, $33^{\circ} 56^{\prime} \mathrm{E}$ (2 우 우), Wadi Itlah $28^{\circ} 35^{\prime} \mathrm{N}, 33^{\circ} 55^{\prime} \mathrm{E}$ (3 우 우, $10^{\star}$ ), Wadi Gebel $28^{\circ} 32^{\prime} \mathrm{N}, 33^{\circ} 55^{\prime} \mathrm{E}$ (4 우 우), Wadi Tinya, $28^{\circ} 34^{\prime} \mathrm{N}, 33^{\circ} 54^{\prime} \mathrm{E}$ (1 + ). H.D.

Details: Observed foraging on A. santolina, Diplotaxis harra (Forssk.) BoIss. and Foeniculum vulgare L.

Distribution: Sinai, Egypt.

\section{Hylaeus oliviae DATHE 2015}

Material: April-July 2013, St Katherine town $28^{\circ} 33^{\prime} \mathrm{N}$, $33^{\circ} 56^{\prime} \mathrm{E}\left(1\right.$ o ), Wadi Itlah $28^{\circ} 35^{\prime} \mathrm{N}, 33^{\circ} 55^{\prime} \mathrm{E}\left(10^{\star}\right)$, Wadi Gebel $28^{\circ} 32^{\prime} \mathrm{N}, 33^{\circ} 55^{\prime} \mathrm{E}$ (1 ㅇ ). H.D.

Details: Observed foraging on Anarrhinum pubescens Fresen. and F. vulgare.

Distribution: First record of this newly described species. First record for world and Egypt.

\section{Family: Halictidae}

\section{Lasioglossum erraticum (BLÜTHGEN, 1931)}

Material: July 2013 - Wadi Tinya, $28^{\circ} 34^{\prime} \mathrm{N}, 33^{\circ} 54^{\prime} \mathrm{E}$ (1 우). A.P.

Details: Observed foraging on A. santolina and Stachys aegyptiaca PERs.

Distribution: Greece, Turkey, Cyprus, Armenia. First record for Egypt. 


\section{Lasioglossum collopiense (PÉREZ 1903)}

Material: July 2013 - Wadi Gebel $28^{\circ} 32^{\prime} \mathrm{N}, 33^{\circ} 55^{\prime} \mathrm{E}$ (1 ㅇ). A.P.

Details: Observed foraging on A. santolina and T. santolinoides.

Distribution: North Africa and the Canaries. First record for Egypt.

\section{Halictus gemmellus PAULY, 2015}

Material: June 2013 -St Katherine town $28^{\circ} 33^{\prime} \mathrm{N}, 33^{\circ} 56^{\prime} \mathrm{E}$ (4 우 우 $10^{\top}$ ), Wadi Rahah $28^{\circ} 34^{\prime} \mathrm{N}, 33^{\circ} 56^{\prime} \mathrm{E}$ (1 우), Wadi Itlah $28^{\circ} 35^{\prime} \mathrm{N}, 33^{\circ} 55^{\prime} \mathrm{E}\left(10^{\top}\right)$, Wadi Gebel $28^{\circ} 32^{\prime} \mathrm{N}, 33^{\circ} 55^{\prime} \mathrm{E}$ (1 9 ). A.P.

Details: Observed foraging on A. santolina, T. santolinoides, Caylusea hexagyna (Forssk.) M.L. Green and F. vulgare

Distribution: West Mediterranean. First record for Egypt.

Family: Megachilidae

Hoplitis africana (WARNCKE, 1990)

Material: April-May 2013 - Wadi Itlah $28^{\circ} 35^{\prime} \mathrm{N}, 33^{\circ} 55^{\prime} \mathrm{E}$ (5 우 ㅇ). A.M.

Details: Observed foraging on Launaea nudicaulis (L.) Hook.f. and C. hexagyna.

Distribution: Northern Africa and South West Asia. First record for Egypt.

Hoplitis epeoliformis (DUCKE, 1899)

Material: May 2013 - Wadi Itlah $28^{\circ} 35^{\prime} \mathrm{N}, 33^{\circ} 55^{\prime} \mathrm{E}$ (1 9 ).

Details: Observed foraging on Peganum harmala L.

Distribution: Northern Africa and Jordan. First record for Egypt.

\section{Hoplitis gerofita (WARNCKE, 1990)}

Material: April-May 2013 - Wadi Itlah $28^{\circ} 35^{\prime} \mathrm{N}, 33^{\circ} 55^{\prime} \mathrm{E}$ (4 우 ㅇ) . A.M.

Details: Observed foraging on Oligomeris linifolia (VAHL) J.F. MACBR., Ochradenus baccatus, TAILY WEED. and C. hexagyna.
Distribution: Jordan, Israel. First record for Egypt.

Hoplitis hofferi TKALCU, 1977

Material: April-June 2012 - St Katherine town $28^{\circ} 33^{\prime} \mathrm{N}$, $33^{\circ} 56^{\prime} \mathrm{E}$ ( 4 우 우, $20^{\circ}$ ), Wadi Rahah $28^{\circ} 34^{\prime} \mathrm{N}, 33^{\circ} 56^{\prime} \mathrm{E}$ (1 우), Wadi Itlah $28^{\circ} 35^{\prime} \mathrm{N}, 33^{\circ} 55^{\prime} \mathrm{E}$ (1 9 ). April-July 2013St Katherine town $28^{\circ} 33^{\prime} \mathrm{N}, 33^{\circ} 56^{\prime} \mathrm{E}\left(20\right.$ 우 , $\left.20^{\star} 0^{\star}\right)$, Wadi Rahah $28^{\circ} 34^{\prime} \mathrm{N}, 33^{\circ} 56^{\prime} \mathrm{E}$ ( 2 우 우, $20^{\top} 0^{\top}$ ), Wadi Itlah $28^{\circ} 35^{\prime} \mathrm{N}, 33^{\circ} 55^{\prime} \mathrm{E}\left(4\right.$ 우 우, $\left.30^{\top} 0^{\top}\right)$, Wadi Gebel $28^{\circ} 32^{\prime} \mathrm{N}$, $33^{\circ} 55^{\prime} \mathrm{E}(1$ ㅇ $)$. A.M.

Details: Observed foraging almost exclusively on P. harmala and C. hexagyna.

Distribution: Israel, Jordan, UAE, Oman, Pakistan. First record for Egypt.

Megachile insignis van der ZANDEN, 1996

Material: May-July 2013 - Wadi Itlah $28^{\circ} 35^{\prime} \mathrm{N}, 33^{\circ} 55^{\prime} \mathrm{E}$ (5 우 우), Wadi Gebel $28^{\circ} 32^{\prime} \mathrm{N}, 33^{\circ} 55^{\prime} \mathrm{E}$ (1 우). C.P.

Details: Observed foraging on Medicago sativa L. and C. hexagyna.

Distribution: Greece, Turkey, Syria, Iran and Israel. First record for Egypt.

Megachile montenegrensis Dours, 1873

Material: April 2012 - St Katherine town $28^{\circ} 33^{\prime} \mathrm{N}, 33^{\circ} 56^{\prime} \mathrm{E}$ (2 우 ㅇ). C.P.

Details: Observed foraging on Colutea istria MiLler.

Distribution: Widespread across southern Palaearctic, including neighbouring Israel. First record for Egypt.

Osmia laticella VAN DER ZANDEN, 1986

Material: April-May 2013 - St Katherine town $28^{\circ} 33^{\prime} \mathrm{N}$, $33^{\circ} 56^{\prime} \mathrm{E}$ (1 우), Wadi Itlah $28^{\circ} 35^{\prime} \mathrm{N}, 33^{\circ} 55^{\prime} \mathrm{E}$ ( 1 우). Wadi Gebel $28^{\circ} 32^{\prime} \mathrm{N}, 33^{\circ} 55^{\prime} \mathrm{E}$ (1 ㅇ), Wadi Tinya, $28^{\circ} 34^{\prime} \mathrm{N}$, $33^{\circ} 54^{\prime} \mathrm{E}$ (3 우 우). A.M.

Details: Observed foraging on Arabidopsis kneuckeri (BorNm.) O. E. Schulz, Z. spinosa and Rosmarinus officinalis L.

Distribution: Israel and Egypt. 
Family: Crabronidae

\section{Bembecinus hebraeus DE BEAUMONT, 1968}

Material: June 2013 - Wadi Itlah $28^{\circ} 35^{\prime} \mathrm{N}, 33^{\circ} 55^{\prime} \mathrm{E}$ ( 1 specimen, sex unknown) Wadi Gebel $28^{\circ} 32^{\prime} \mathrm{N}, 33^{\circ} 55^{\prime} \mathrm{E}$ (1 specimen, sex unknown). C.S-E.

Distribution: Previously only recorded in Israel. First record for Egypt.

\section{DIPTERA}

\section{Family: Syrphidae}

\section{Eristalis arbustorum (LINNAEUS, 1758)}

Material: July 2012 - St Katherine town $28^{\circ} 33^{\prime} \mathrm{N}, 33^{\circ} 56^{\prime} \mathrm{E}$ (1 specimen, sex unknown). F.G.

Details: Observed foraging on A. santolina.

Distribution: Widespread across Europe, Northern Africa and Asia (Syria, Iran and Afghanistan). First record for Egypt.

\section{Melanostoma scalare (FABRICIUS, 1794)}

Material: April 2012 - Sheik a Wad $28^{\circ} 38^{\prime} \mathrm{N}, 33^{\circ} 53^{\prime} \mathrm{E}$ ( 1 specimen, sex unknown), Wadi Itlah $28^{\circ} 35^{\prime} \mathrm{N}, 33^{\circ} 55^{\prime} \mathrm{E}$ (1 specimen, sex unknown). F.G.

Details: Observed foraging on O. baccatus and Eruca sativa MiLL.

Distribution: Western Europe. First record for Egypt.

\section{Family: Tephritidae}

\section{Katonaia aida HERING, 1938}

Material: July 2013 - Wadi Itlah $28^{\circ} 35^{\prime} \mathrm{N}, 33^{\circ} 55^{\prime} \mathrm{E}$ (1 specimen, sex unknown). A.F.

Details: Host plant: Lamiacae Ballota spp. but observed foraging on A. santolina.

Distribution: Israel and Egypt.

\section{Discussion}

Here we provide an initial checklist of some of the flower visitor fauna of the St Katherine Protectorate. Out of the 112 species recorded, thirteen were new records for Egypt, highlighting the importance of continued pollinator research in the region. Solitary bees were the most diverse group of flower visitors with 53 species, which is just $10 \%$ of Egypt's previously recorded bee species (427 species). Despite this low representation of Egypt's current species list, we recorded eleven bee species that were new records for the country, including the previously undescribed Hylaeus oliviae (described in DATHE, 2015).

The specimens in this study were collected between April and July, but flower visitors are known to be active both earlier and later in the season. Previous expeditions in August documented four additional bee species (Anthophora albigena, Xylocopa pubescens, Chalicodoma maxillosa, Megachile submucida) (ZALAt et al., 2009), suggesting that the Protectorate actually supports at least 57 bee species. Similar numbers of bee species have been reported in the Suez Canal region to the north of Sinai (62 species) (SHeBl et al., 2013, 2015), but despite the relatively close proximity of the sites, only eight of the species recorded in Suez were found in the St Katherine Protectorate. This high heterogeneity of species composition suggests that there is still much to learn about bee fauna across the Sinai Peninsula and that current species lists may be underestimates.

The St Katherine Protectorate supports a number of flower visitors that are regional endemics, such as the tephritid fly Katonaia aida (Israel and Egypt) and sand wasp Bembecinus hebraeus (Israel and Egypt). The solitary bees showed the highest levels of such regional endemism, with four species restricted to the Egypt and Israel region (Anthophorahermanni, Hylaeus sinaiticus, Hylaeus oliviae, Osmia laticella) and three with slightly wider ranges, i.e. Anthophora pauperata (Egypt, Saudi Arabia), Anthophora caelebs (Libya, Egypt, Israel), Hoplitis gerofita (Egypt, Israel, Jordan). These levels of regional endemism ( $13 \%$ of the bee community) were much higher than those observed in other flower visitor groups, notably the hoverflies, which were dominated by widespread species.

Overall, this study provides a valuable initial checklist of flower-visiting insects within the St Katherine Protectorate. It is very likely that more undescribed species await discovery. This, together with the high proportion of new records for Egypt, suggests that species numbers are likely to be underestimated. We highlight the need for future research into the Egyptian pollinator fauna, particularly within the St Katherine Protectorate, where our surveys discovered undescribed and possibly endemic species.

\section{References}

Archer, C. R.; Pirk, C. W. W.; Carvalheiro, L. G. \& Nicolson, S. W. 2014: Economic and ecological implications of geographic bias in pollinator ecology in the light of pollinator declines. - Oikos 123: 401-407. 
Ayyad, M. A.; Fakhry, A. M. \& Moustafa, A. R. A. 2000: Plant biodiversity in the St. Catherine area of the Sinai peninsula, Egypt. - Biodiversity Conservation 9: 265-281.

Chaplin-Kramer, R.; Dombeck, E.; Gerber, J.; Knuth, K. A.; Mueller, N. D.; Mueller, M.; Ziv, G. \& KLeIN, A.-M. 2014: Global malnutrition overlaps with pollinator-dependent micronutrient production. Proceedings of the Royal Society B, Biological Sciences 281: 1794

Dathe, H. H. 2015: Studies on the systematics and taxonomy of the genus Hylaeus F. (10): New descriptions and records of Asian Hylaeus species (Hymenoptera: Anthophila, Colletidae). - Contributions to Entomology 65 (2): 223-238.

El-Hawagry, M. \& GilberT, F. 2014: Zoogeographical affinities and faunal relationships of bee flies (Diptera: Bombyliidae) in Egypt. - Zoology in the Middle East 60: $50-56$.

Gallai, N.; Salles, J.-M.; Settele, J. \& Vaissière, B. E. 2009: Economic valuation of the vulnerability of world agriculture confronted with pollinator decline. - Ecological economics 68: 810-821.

Garibaldi, L. A.; Steffan-Dewenter, I.; Winfree, R.; Aizen, M. A.; Bommarco, R.; Cunningham, S. A.; Kremen, C.; Carvalheiro, L. G.; Harder, L. D. \& AfIK, O. 2013: Wild pollinators enhance fruit set of crops regardless of honey bee abundance. - Science 339: 1608-1611.

Kuhlmann, M.; Ascher, J. S.; Dathe, H. H.; Ebmer, A. W.; Hartmann, P.; Michez, D.; Müller, A.; Patiny, S.; $\quad$ Pauly, A.; $\quad$ Praz, C.; $\quad$ Rasmont, P.; Risch, S.; Scheuchl, E.; Schwarz, M.; Terzo, M.; Williams, P. H.; Аmiet, F.; Baldock, D.; Berg, $\varnothing . ;$ Bogusch, P.; Calabuig, I.; Cederberg, B.; Gogala, A.; Gusenleitner, F.; Josan, Z; Madsen, H. B.; Nilsson, A.; Ødegaard, F.; OrtizSanchez, J.; Paukkunen, J.; Pawlikowski, T.; Quaranta, M.; Roberts, S. P. M.; Sáropataki, M.; Schwenninger, H.-R.; Smit, J.; Söderman, G. \& TomozeI, B. 2017: Checklist of the Western Palaearctic Bees. Hymenoptera: Apoidea: Anthophila. - http:// westpalbees.myspecies.info [Accessed 27/07/2014].

Klein, A.-M.; Vaissière, B. E.; Cane, J. H.; SteffanDewenter, I.; Cunningham, S. A.; Kremen, C. \& TsCharntKe, T. 2007: Importance of pollinators in changing landscapes for world crops. - Proceedings of the Royal Society B, Biological Sciences 274: 303-313.

Kugler, J. \& Freidberg, A. 1975: A list of the fruit flies (Diptera: Tephritidae) of Israel and nearby areas, their host plants and distribution. - Israel Journal of Entomology 10: 51-72.

LARsen, T. 1990: The butterflies of Egypt. - American University in Cairo Press, Denmark (Cairo \& Apollo Books).
Mayer, C.; Adler, L.; Armbruster, S.; Dafni, A.; Eardley, C.; Huang, S.; Kevan, P.; Ollerton, J.; Packer, L. \& Ssymank, A. 2011: Pollination ecology in the 21st century: key questions for future research. - Journal of Pollination Ecology 3: 8-23.

Norfolk, O.; Abdel-Dayem, M. \& Gilbert, F. 2012: Rainwater harvesting and arthropod biodiversity within an arid agro-ecosystem. - Agriculture, Ecosystems \& Environment 162: 8-14.

Norfolk, O.; Eichhorn, M. P. \& Gilbert, F. 2016: Flowering ground vegetation benefits wild pollinators and fruit set of almond within arid smallholder orchards. - Insect Conservation and Diversity 9: 236-243.

Pauly, A. 2011: Atlas of the European Bees: genus Halictus, subgenus Seladonia. - STEP Project, Atlas Hymenoptera, Mons, Gembloux. - http://www. zoologie.umh.ac.be/hymenoptera/page.asp? $\mathrm{ID}=194$ [Accessed: 27/07/2014].

Pauly, A. 2016: Les Dialictus Robertson, 1902 de la Région Paléarctique. Atlas Hymenoptera. - http:// www.atlashymenoptera.net/page.asp? $\mathrm{id}=128$ [Accessed: 27/07/2016].

Peck, L. V. 1988: Family Syrphidae. - In: Soos, A.; Papp, L. Eds.), Catalogue of Palaearctic Diptera, Vol. 8. Syrphidae - Conopidae. - Amsterdam: Elsevier: 11-230.

Potts, S. G.; Biesmeijer, J. C.; Kremen, C.; Neumann, P.; Schweiger, O. \& Kunin, W. E. 2010: Global pollinator declines: trends, impacts and drivers. Trends in ecology \& evolution 25: 345-353.

Rasmont, P. 2014: Atlas of the European Bees: genus Amegilla. 1st Edition. - STEP Project, Atlas Hymenoptera, Mons, Gembloux. - http://www. atlashymenoptera.net/page.asp?ID=259 [Accessed: 27/07/2016].

Schmid-Egger, C. 2004: Revision of Bembecinus Hymenoptera: Crabronidae) of the Palaearctic region. - Notes fauniques de Gembloux 54: 3-69.

Schuh, R. T.; Hewson-Smith, S. \& Ascher, J. S. 2010: Specimen databases: A case study in entomology using web-based software. - American Entomologist 56: 206-216.

Semida, F. M.; Abdel-Dayem, M. S.; Zalat, S. M. \& Gilbert, F. S. 2001: Habitat heterogeneity and altitudinal gradients in relation to beetle diversity in South Sinai, Egypt. - Egyptian Journal of Biology 3: 137-146.

Shebl, M.; Kamel, S. \& Mahfouz, H. 2013: Bee fauna (Apoidea: Hymenoptera) of the Suez Canal Region, Egypt. - Journal of Apicultural Science 57: 33-44.

Shebl, M. A; Patiny, S. \& Michez, D. 2015: Supplementary note on the solitary bee fauna from the Suez Canal region of Egypt. Hymenoptera: Apoidea. Journal of Melittology 47: 1-5. 
Steward, P. R.; Shackelford, G.; Carvalheiro, L. G.; Benton, T. G.; Garibaldi, L. A. \& Sait, S. M. 2014: Pollination and biological control research: are we neglecting two billion smallholders. - Agriculture \& Food Security 3: 1.

Zalat, S.; Gilbert, F.; Fadel, H.; El-Hawagry, M. S.; SAleh, M.; Kamel, S. \& Gilbert, J. 2009: Biological explorations of Sinai: flora and fauna of Wadi Isla and Hebran, St Katherine Protectorate, Egypt. - Egyptian Journal of Natural History 5: 6-15.
Zalat, S.; Semida, F.; Gilbert, F.; El Banna, S.; Sayed, E.; El-Alqamy, H. \& Behnke, J. 2001: Spatial variation in the biodiversity of Bedouin gardens in the St. Katherine Protectorate. - Egyptian Journal of Biology 3: 147-155.

Tab. 1: Full species list of flower visitors observed within the St Katherine Protectorate in 2012 and 2013. E = new records for Egypt; $\mathrm{S}=$ records of new species; $(\mathrm{S})=$ possible records of new species pending description.

\begin{tabular}{|c|c|c|}
\hline & & $\begin{array}{l}\text { Number of } \\
\text { individuals } \\
\text { observed }\end{array}$ \\
\hline \multicolumn{3}{|l|}{ COLEOPTERA } \\
\hline Buprestidae & & 32 \\
\hline \multicolumn{3}{|l|}{ Anthaxia scutellaris GÉNÉ, 1839} \\
\hline \multicolumn{3}{|l|}{ Coccinellidae } \\
\hline Coccinella septempunctata LinNaEUs, 1758 & & 133 \\
\hline \multicolumn{3}{|l|}{ DIPTERA } \\
\hline \multicolumn{3}{|l|}{ Syrphidae } \\
\hline Eristalinus aeneus (ScOPOLI, 1763) & & 22 \\
\hline Eristalinus taeniops (WIEDEMANN, 1818) & & 7 \\
\hline Eristalis arbustorum (LINNAEUs, 1758) & $\mathrm{E}$ & 1 \\
\hline Eristalis tenax (LinnaEus, 1758) & & 14 \\
\hline Eumerus vestitus BEZZI, 1912 & & 1 \\
\hline Eupeodes corollae (FABRICIUS, 1794) & & 177 \\
\hline Ischiodon aegyptius (WIEDEMANN, 1830) & & 47 \\
\hline Melanostoma scalare (FABRICIUs, 1794) & $\mathrm{E}$ & 2 \\
\hline Paragus tibialis (FALLÉN, 1817) & & 2 \\
\hline Scaeva albomaculata (MACQUART, 1842) & & 7 \\
\hline Sphaerophoria rueppellii WEIDEMANN, 1820 & & 22 \\
\hline Sphaerophoria scripta (LinNaEus, 1758) & & 46 \\
\hline Syritta fasciata (WIEDEMANN, 1830) & & 250 \\
\hline \multicolumn{3}{|l|}{ Tephritidae } \\
\hline Acanthiophilus helianthi (Rossi) & & 22 \\
\hline Capitites augur (FRAUENFELD) & & 2 \\
\hline Carpomya incompleta (BECKER) & & 3 \\
\hline Dacus ciliatus (LoEw) & & 1 \\
\hline Euarestella iphionae (EFFLATOUN) & & 9 \\
\hline Goniurellia spinifera FREIDBERG & & 1 \\
\hline Katonaia aida HERING & & 1 \\
\hline Oxyaciura tibialis (R.D.) & & 1 \\
\hline Trupanea amoena (FRAUENFELD) & & 3 \\
\hline Trupanea pulcherrima (EFflatoun) & & 3 \\
\hline
\end{tabular}




\begin{tabular}{|c|c|c|}
\hline & & $\begin{array}{l}\text { Number of } \\
\text { individuals } \\
\text { observed }\end{array}$ \\
\hline \multicolumn{3}{|l|}{ HEMIPTERA } \\
\hline \multicolumn{3}{|l|}{ Lygaeidae } \\
\hline Spilostethus pandurus (Scopoli, 1763) & & 4 \\
\hline \multicolumn{3}{|l|}{ HYMENOPTERA } \\
\hline \multicolumn{3}{|l|}{ Apidae } \\
\hline Amegilla cognata (Sмiтн, 1854) & & 5 \\
\hline Amegilla mucorea (KLUG, 1845) & & 28 \\
\hline Amegilla savignyi (LEPELETIER, 1841) & & 7 \\
\hline Anthophora caelebs GRIBODO, 1924 & & 3 \\
\hline Anthophora concinna (KLUG, 1845) & & 27 \\
\hline Anthophora (Heliophila) SinAI sp1 & $(\mathrm{S})$ & 5 \\
\hline Anthophora crassipes LEPELETIER, 1841 & & 19 \\
\hline Anthophora hermanni SCHWARZ \& GUSENLEITNER, 2003 & & 4 \\
\hline Anthophora pauperata WALKER, 1871 & & 8 \\
\hline Anthophora senescens LEPELETIER, 1841 & & 1 \\
\hline Anthophora SinAI sp1 & $(\mathrm{S})$ & 51 \\
\hline Apis cerana FABRICIUS, 1793 & & 2 \\
\hline Apis mellifera LinNaEus, 1758 & & 300 \\
\hline Xylocopa sulcatipes MAA, 1970 & & 28 \\
\hline \multicolumn{3}{|l|}{ Colletidae } \\
\hline Colletes nanus FrIESE, 1898 & & 5 \\
\hline Colletes perezi MoRICE, 1904 & & 20 \\
\hline Colletes pumilus MORICE, 1904 & & 1 \\
\hline Colletes tuberculatus Morawitz, 1894 & $\mathrm{E}$ & 1 \\
\hline Hylaeus sinaiticus (ALFKeN, 1938) & & 16 \\
\hline Hylaeus oliviae DATHE, 2015 & S & 3 \\
\hline Hylaeus xanthopoda (VACHAL, 1895) & & 8 \\
\hline Hylaeus albonotatus (WALKER, 1871) & & 12 \\
\hline \multicolumn{3}{|l|}{ Crabronidae } \\
\hline Bembecinus hebraeus DE BEAumont, 1968 & $\mathrm{E}$ & 3 \\
\hline Bembix arenaria HANDLIRSCH, 1893 & & 1 \\
\hline Bembix oculata PANzer, 1801 & & 7 \\
\hline Cerceris alboatra Мосні, 1938 & & 5 \\
\hline Cerceris sabulosa (PANZER, 1799) & & 31 \\
\hline Cerceris tricolorata МоснI, 1938 & & 8 \\
\hline Palarus histrio SPINOLA, 1838 & & 1 \\
\hline Philanthus coarctatus SPINOLA, 1839 & & 16 \\
\hline Philanthus triangulum (FABRICIUS, 1775) & & 9 \\
\hline Prosopigastra fumipennis GussakovsKIJ, 1952 & & 2 \\
\hline
\end{tabular}




\begin{tabular}{|c|c|c|}
\hline & & $\begin{array}{l}\text { Number of } \\
\text { individuals } \\
\text { observed }\end{array}$ \\
\hline \multicolumn{3}{|l|}{ Halictidae } \\
\hline Ceylalictus variegatus (Olivier, 1789) & & 5 \\
\hline Halictus tibalis WALKER, 1871 & & 12 \\
\hline Halictus gemmellus Pauly, 2015 & & 7 \\
\hline Halictus falx EBMER, 2008 & & 4 \\
\hline Halictus pici PÉREZ, 1895 & & 5 \\
\hline Lasioglossum erraticum (BLÜTHGEN, 1931) & $\mathrm{E}$ & 1 \\
\hline Lasioglossum kowitense (COCKERELL, 1937) & & 1 \\
\hline Lasioglossum subaenescens asiaticum (DALLA Torre, 1896) & & 3 \\
\hline Lassioglossum collopiense (PÉREz, 1903) & $\mathrm{E}$ & 1 \\
\hline Nomioides rotundiceps HANDLIRSCH, 1888 & & 3 \\
\hline Nomioides squamiger SAUNDERS, 1908 & & 1 \\
\hline Nomioides turanicus MorawTIZ, 1876 & & 14 \\
\hline Pseudapis nilotica (SмIтн, 1875) & & 2 \\
\hline \multicolumn{3}{|l|}{ Megachilidae } \\
\hline Anthidium amabile AlfKen, 1932 & & 1 \\
\hline Anthidium bischoffi Mavromoustakis, 1954 & & 3 \\
\hline Chalicodoma montenegrense Dours, 1873 & & 2 \\
\hline Hoplitis africana (WARNCKE, 1990) & $\mathrm{E}$ & 5 \\
\hline Hoplitis epeoliformis (DuCKE, 1899) & $\mathrm{E}$ & 1 \\
\hline Hoplitis gerofita (WARNCKE, 1990) & $\mathrm{E}$ & 4 \\
\hline Hoplitis hofferi TKALCŮ, 1977 & $\mathrm{E}$ & 42 \\
\hline Icteranthidium ferrugineum FABRICIUS, 1787 & & 4 \\
\hline Megachile concinna Sмгтн, 1879 & & 3 \\
\hline Megachile inexspectata ReBmann, 1968 & & 1 \\
\hline Megachile doriae MagretTI, 1890 & & 1 \\
\hline Megachile flabellipes PÉREZ, 1895 & & 1 \\
\hline Megachile insignis VAN DER ZANDEN, 1996 & $\mathrm{E}$ & 6 \\
\hline Megachile minutissima Radoszkowsкi, 1876 & & 1 \\
\hline Megachile montenegrensis Dours, 1873 & $\mathrm{E}$ & 4 \\
\hline Megachile tenuistriga AlfKen, 1938 & & 2 \\
\hline Megachile walkeri Dalla ToRre, 1896 & & 65 \\
\hline Osmia alfkenii Ducke, 1900 & & 1 \\
\hline Osmia laticella VAN DER ZANDEN, 1986 & & 6 \\
\hline \multicolumn{3}{|l|}{ Scoliidae } \\
\hline Scolia carbonaria (LinNAEUs, 1767) & & 6 \\
\hline \multicolumn{3}{|l|}{ Sphecidae } \\
\hline Chalybion flebile (LEPELETIER, 1845) & & 1 \\
\hline Podalonia tydei (Le Guillou, 1841) & & 1 \\
\hline
\end{tabular}




\begin{tabular}{|c|c|}
\hline & $\begin{array}{l}\text { Number of } \\
\text { individuals } \\
\text { observed }\end{array}$ \\
\hline \multicolumn{2}{|l|}{ Vespidae } \\
\hline Celonites fischeri SPINOLA, 1838 & 1 \\
\hline Vespa orientalis LinnaEus, 1771 & 2 \\
\hline \multicolumn{2}{|l|}{ LEPIDOPTERA } \\
\hline \multicolumn{2}{|l|}{ Hesperiidae } \\
\hline Spialia doris (WALKER, 1870) & 5 \\
\hline \multicolumn{2}{|l|}{ Lycaenidae } \\
\hline Agrodiaetus loewii ZELLER, 1847 & 5 \\
\hline Deudorix livia (KLUG, 1834) & 5 \\
\hline Iolana alfierii WILTSHIRE, 1948 & 10 \\
\hline Lampides boeticus (LinNAEUs, 1767) & 348 \\
\hline Leptotes pirithous (LINNAEUs, 1767) & 39 \\
\hline Tarucus rosacea (Austaut, 1885) & 85 \\
\hline Polyommatus icarus (RotTemburg, 1775) & 1 \\
\hline \multicolumn{2}{|l|}{ Nymphalidae } \\
\hline Danaus chrysippus (LinnaEus, 1758) & 3 \\
\hline Vanessa cardui (LinnAEus, 1758) & 4 \\
\hline \multicolumn{2}{|l|}{ Pieridae } \\
\hline Belenois aurota (FABRICIUs, 1793) & 24 \\
\hline Colias croceus (GEOFFroy, 1785) & 4 \\
\hline Colotis fausta (OLIVIER, 1804) & 2 \\
\hline Pieris rapae (Linnaeus, 1758) & 4 \\
\hline Pontia daplidice (LinnaEus, 1758) & 17 \\
\hline Pontia glauconome KLUG, 1829 & 1 \\
\hline \multicolumn{2}{|l|}{ Sphingidae } \\
\hline Macroglossum stellatarum (LinNAEus, 1758) & 7 \\
\hline
\end{tabular}

